\title{
The past and present of Érmellék wine region
}

\author{
Klára Ágnes Kiss \\ University of Debrecen Centre of Agricultural and Applied Economic Sciences, \\ Faculty for Agricultural and Food Sciences and Environmental Management, Kerpely Kálmán Doctoral School, Debrecen \\ kiss.klara@agr.unideb.hu
}

SUMMARY

\begin{abstract}
Érmellék is an area of the Partium. It is situated between Szilágy and Bihar counties and between River Kraszna and Berettyó. Its name is from Ér, the small brook, which crosses the area. Érmellék is famous for its wine production, because its climate is favourable for this kind of trade. Only a few information sheets of the small Partium-belonging micro-region, Érmellék are published nowadays. Érmellék has extremely picturesque architectural wine cellar rows, of which "szalacsi" wine cellar row (wine cellar row system) with its unique structure consists of about a thousand cellars.
\end{abstract}

Keywords: Érmellék, wine, wine region, wine tourism

ÖSSZEFOGLALÁS

Az Érmellék a Partium egyik térsége. Elhelyezkedése Bihar és Szilágy megyék közé tehetö, Kraszna és Berettyó folyók közé. Nevét a rajta áthaladó Ér-röl kapta. Érmellék hires a bortermeléséröl, mivel éghajlata nagyon kedvezö erre a mesterségre. A Partiumhoz tartozó mikrorégióról, Érmellékröl kevés ismertetö jellegü irás jelenik meg mostanában. Az Érmellék rendkivül változatos épitészetü pincesorokkal rendelkezik, külön kiemelendö a teljesen egyedülálló és egyedi kialakitású szalacsi pincesor, helyesebben pincesorrendszer, amely megközelitöleg ezer pincéből áll.

Kulcsszavak: Érmellék, bor, borrégió, borturizmus

\section{THE AIM OF THE STUDY}

Wine has its credit, plenty. It is drunk eachwhere as a nepenthe or remedy, not only at christenings, and funeral feasts, but preferably day by day, sometimes by necessity. In Europe, there is not such a suitable place for wine-growing as in Erdély. Erdély wine has always been treasure for the inhabitants who suffered from pressure throughout the history. Wine-growing in Erdély has been in its biggest crisis since the wine-pest and promise for the future can be brought from the past only. Viniculture and wine-growing is the profession, which means both culture and prosperity. Present cannot be evaluated without knowledge of the past (Csávossy, 2002).

\section{ABOUT ÉRMELLÉK}

The name, brook Ér has already occured in the $13^{\text {th }}$ century: Anonymus as Humusouer mentioned it. In the collection of documents of the Károlyi family it is called Erwize fluvius and later Eer fluvius (around 1338). Érmellék as a regional name occured for the first time in the collection of documents of Leles's praepositus in 1445 by mentioning the borders of Éradony as the name of Ermellek terrae arabilis. The basin of Ér has been formed during million years. Effects of the 250 million year-old Hercinia mountain range are noticeable in the deep: one of its breaking lines in the deep extends to under Érmellék. The thick sediment of Pannon Sea was deposited on it and the explanation is that from the Cretaceous period the crystal structured base were gradually sinking. Today's formation of surface of Érmellék was caused by warmings between freezings when melted wate was running towards the Great Hungarian Plain. River Szamos, Tisza and Kraszna played an important role in the formation of Érmellék. When the weather was dry, the wind left loess and dust coating from silt. In the boggy, swampy areas rich flora and fauna evolved, while in higher areas, woods and lawns were forming. Where Kraszna also leaves the valley, there is Ér, the little brook from Szekeres forest. Érmellék has extremely picturesque architectural wine cellar rows, of which "szalacsi" wine cellar row (wine cellar row system) with its unique structure consists of about a thousand cellars (figure 1).

Figure 1: Szalacsi winecellars in Érmellék

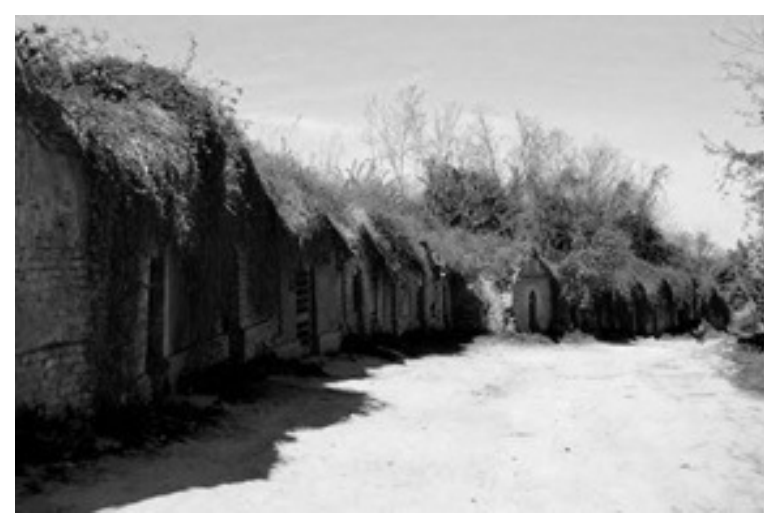

Source: Net 1

The Turks, far away from Mecca liked bakator (kind of grape, also called bakar) very much. During the times of Turkish occupation both wine-growing and plunder were prospering. As a chronicler wrote down: "Turks from Várad and Szentjobb often go out among 
them, they hit down the locks or take the keys with them, drink and waste their wine but do not pay its cost back." Bakar or bakatel is now a Hungaricum and what is more it is a Transsilvanicum. The Bakator grape is a very delicate and native Hungarian kind, which has qiute a difficult pollination. The name, Bakar is originated from Kabar tribes who joined the first Hungarian settlers but others think that it is from the Italian name, Bacca d'ore. Although it is a red kind of grape, its name means golden berry. Today Érmellék is situated on Ér flat, the area from Kraszna to Berrettyó, Nyírségi hills and Szilágysági hills. At present its area can be estimated about $1600 \mathrm{~km}^{2}$. Its climate can be defined by observations in the nearest towns (Nagyvárad, Nagykároly), unfortunately there are no accurate datas. The climate of Émellék is determined by its geographical situation.

This name (Érmellék) has a strange melody just as Ér was a strange and misterious river with the unique fauna of its swamps, its tempting woods, the scent of wattles and wine. This land with its force of production is inhabited by smart and hard-working people that is indurated by history. Érmellék is a specific area of the historical Bihar, Szilágy and Szatmár counties. Its name is originated from Ér, the "big, strange ditch", of which Ady Endre, who was born in Érmindszent wrote a poem. Original River Tisza used to meander here, and during the ice-age, Szamos did. Making nothing of environmental respects, the rich wildlife of this unique corner of the Carpathian basin was destroyed. Later Érmellék was pronounced as an area that is suitable for cultivation even though its swampy soil is not proper for farming, because in drought it moulders and when it is raining, it becomes mud. Natura 2000 also mapped the area for an environmental program: since European Union helps to make a small area swampy again. In pursuance of this fact, Ér could be a green corridor again.

\section{HISTORY OF ÉRMELLÉK}

We have to go back to the $13^{\text {th }}$ century for getting to know about the very start of local wine-growing. According to our lights, the Great Tartar Invasion century means the sedentation of Érmellék (called Ómosóér those days) wine culture and it is interesting that even the destructive attack against Hungary then could not prevent its undiminished development.The first golden age of Érmellék wine-growing was during King (Hunyadi) Mátyás I, but it is not clear that in this period this area was only the usufructuary of the country's general upswing those days or the inhabitatants deserved attention as well. The latter seems to be provable because in the $15^{\text {th }}$ century, people decisively lived on wine- growing and production such as almost the whole population of Kágya village.

After seizing back Várad (1692), Érmellék was a beloved pleasure resort for people from Debrecen and according to Borbély (1993), "it meant title and authority among Debrecen's wealthy citizens to possess a vineyard in Érmellék". From the $18^{\text {th }}$ century however, in agriculture (including wine-growing of course) the so called allodial farming gathered ground gradually and as a matter of fact promoted the birth of professional wine-growing. In this process of course neither the villeins nor
Debrecen's citizens were the main characters, but principally the richest families of the country, such as the Zichy, Stubenberg or Károlyi families. Earl Ferenc Zichy appointed Bihardiószeg as the centre of Érmellék wine-growing, equipped its farms with modern tools and machines and by this, the career of Érmellék wines started out nationwide and in Europe as well. But regrettably the second golden age of local wine-growing was broken in two by the grape-louse (phylloxera) in Europe. In the fight down of phylloxera in Hungary, wine-growers in Érmellék took an active and substantive part and it is not accidental that the first vine-dresser school of the country was established in this area at the end of the $19^{\text {th }}$ century. After arresting phylloxera winegrowers in Érmellék found themselves surprisingly quickly, they planted more tenacious species and took an active role in starting oneology education. The dynamic development of the region broke when Hungarianspeaking agricultural middle and higher education was changed by Romanian-speaking education and thanks to the serial realignments regional wine-growing was totally changed.

\section{THE PAST OF ÉRMELLÉK}

The wine-growing past of Hungarians probably goes back to the settlement, but wine was already known even in the original homeland centuries ago. In the $10^{\text {th }}$ century, Ibn Roszteh Arabic writer stated that Hungarians who lived in the original homeland not only did animal-husbandry, but farming and winegrowing as well. At the end of the $13^{\text {th }}$ century, winedrinking was not only the sumptousness of the high society but the opportunity for a little drop of comfort. From the $13^{\text {th }}$ century on wine-growing was popular among citizens as well and they planted grapes in their gardensand villages. There were many vineyard owners among citizens of Torda, Kolozsvár and Nagyvárad who made his land cultivated by cotters and the poor from the countryside (Entz and Gyurki, 1868).

In the $15^{\text {th }}$ century vineyards can be found even in places where later; because of the unfavourable circumstances and the poor quality of wine, there were no trace of them. The explanation for this kind of grape-planting were self-suffiency and difficulties in transport. The standards of wine-growing were rough and it did not change throughout centuries. Fermentation happened in wooden barrels in the cellars or even in an open-place. During the the reign of King Matthias wine-growing was prospering again; on his wedding, according to the traditions, people drank "erdélyihelyaljai" wine and it is also stated that by means of the good relationship between King Matthias and Stefan cel Mare "Kövér" grape kind got to Cotnari from Erdély. Erdély is the cradle of wines. It has already mentioned as "Küküllők vidékes Weingebiet" (wine region) on János Honterus's map, called Transilvane, published in Basel in 1532. "Gyula fehérvári" wine region has been called "Tara vinului" (wine of wines) by Romanians in Erdély for a long time. The quality of wine is decisively affected by its producting place. Without effacing the signs that refer to the strain, it gives a particular basic flavour featuring the given wine-region, of which the igin of the wine can be recognised easily. 


\section{THE PRESENT OF ÉRMELLÉK}

It seems that Érmellék wine-region exists only in a kind of hibernated state and the stake of the near future would be that if this region gets up from its dream and if the old days come back. It would be obvious to mention Trianon again, and tell that "all went wrong that time" and we can see that Érmellék wine-growing suffered the first punches not during phylloxera, but after the "Big War" (Vofkori, 1994). Unfortunately, wine-cellar rows in érmellék are in a bad condition at present, it seems, that in the last 100 years not much was appropriated on this part of Hungarian Cultural Heritage. As a start, the creation of the conditions for rural tourism would do (infrastructure development, settlement rehabilitation etc.), and afterwards the creation of Érmellék wine route. From the opportunities mentioned in the book, we would choose the so called classic wine route, because on the one hand we think that Érmellék culture region has the sights for it (Ádám et al., 1999). On the other hand, Érmellék has excellent touristical facilities and the outbreak of the region in the third thousand years could be the revitalization of a modern and qualitative wine-growing.

\section{OPPORTUNITIES}

In point of tourism situation in world-economy is favourable, since this is the industry that is growing the most dynamically at present and in the future. The situation of Middle-Europe and Érmellék could be reassuring because theoritically, there are many opportunities for touristic developments. It can be said that its real values worth for development root in the historical past, but have staled by today and have been forgotten. Some of Hungarian guidebooks discuss this area but foreign books hardly mention it. The situation in Romania regarding the measure of incomes has been deteriorating continually since the change of regime, while the number of foreigners who take part in tourism has been growing year by year. Temporarily, mainly less-spender tourists arrive at Romania. It means that the bases of conditions of qualitative tourism have not created yet. In international respects, it can be said about its place in Middle-Europe that of international tourist arrivals Romania shares about $20 \%$ and of incomes this number is less than $10 \%$.

The North-West part of Erdély does not have significant statistic markers, as it is shown in the following data. Unfortunately, only a small part of it is realized in the area of Érmellék. Evaluating generally the attractiveness of Érmellék, it can be defined that it is a rich and various area, but a significant part of its attractions only have regional reaches. There are very few national or international attractions.

Wine tourism

- In the connection between wine and tourism, I would like to emphasize three things:
- Wine for itself as a gastronomic speciality and popular drink comes through and can be seductive as well.

- Wine can be the image creating source and symbol of a particular wine-region, settlement, region or even the country.

The historical Ermellék wine region has excellent facilities where open wine routes, wine-tasting places, thematic wine routes, wine tasting routes and classic wine routes can be organized. Open wine-route is a loose network of wine-tasting places, where teams prepared for tasting and dining wait for the guests. In the case of thematic wine-routes, wine-tasting places are completed with special programs (culture, nature, gastronomy). The biggest opportunity is in classic wineroutes, where there is a particular route to walk along, there are wines selling and tasting places (wine cellar rows: Székelyhíd, Szalacs, Bihardiószeg), accomodation, programs, sights and information boards to give direction to the guests. Regarding rural tourism, small regional association and civil organization should be set up with the accomplishment of common marketing. An important task is organizing educational programs and developing complex services. We should make the best of potential opportunities of the so called "homesick tourism" and demonstrate the drink and gastronomic specialities of the region. From this aspect it can be very important to adopt the experiences from Hungary, where there are national and county organizations of rural tourism, of which work is continuous and give a lot of help with the membrship (figure 2).

\section{Figure 2: The Oneologic Map of Hungary in 1884}

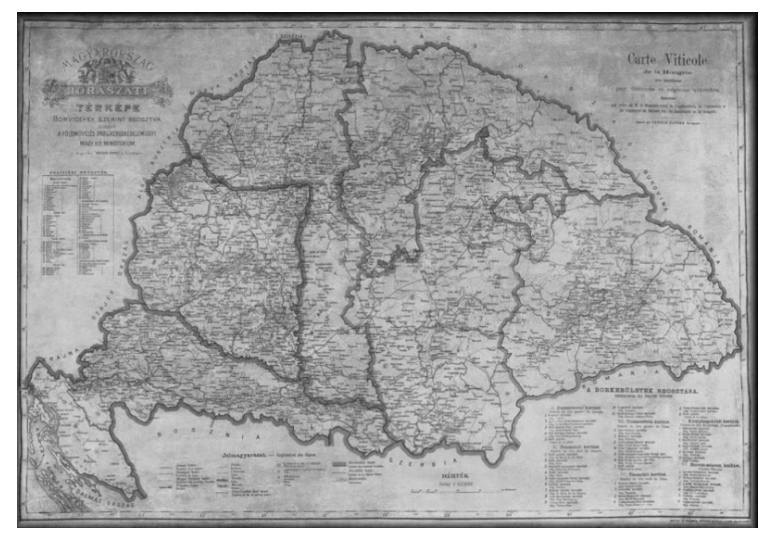

Source: Net 2

\section{ACKNOWLEDGEMENT}

The publication prepared by TÁMOP-4.2.2/B-10/ 1-2010-0024 project.

The project is supported by European Union, by the European Social co-funding. 


\section{REFERENCES}

Ádám L.-Belia Gy.-Csatári D.-Kosály M.-Kovács Gy.-Szávai J. (1999): Románia. Panoráma Útikönyvek. Budapest.

Borbély G. (1993): Szőlőművelés és borgazdálkodása az Érmelléken. Nagyvárad.

Csávossy Gy. (2002): Jó boroknak szép hazája, Erdély. Mezőgazda Kiadó. Budapest.
Entz F.-Gyurki A. (1868): A hazai szőlészet. Budapest.

Net 1: http://mw2.google.com/mw-panoramio/photos/medium/ 54324559.jpg

Net 2: http://www.terkep-center.hu/galeria/orig/38_boraszat.jpg

Vofkori L. (1994): Falusi turizmus Erdélyben. MTA Társadalomkutató Központ. Budapest. 